\title{
A STUDY ON MOVEMENT OF BSE SHARE PRICES DURING ELECTIONS 2014
}

\author{
*Dr. Nagaraju Y
}

\section{ABSTRACT}

Stock markets are more sensitive to the changes that occur in the environment. Among the several factors causing volatility in the stock market index, investor psychology is one of the important factors which lead to change in the Sensex. Investor psychology before and after general elections has shown a significant change over the years. In India general elections are to be held in definite time intervals, but in reality, it happens more frequently. The parliamentary elections held in the year 2014 are one of the biggest and longest elections in the country. It was held in nine phases from 7 th April 2014 to 12 th May 2014. This paper attempts to study the impact of Loksabha polls 2014 on BSE Sensex and on different industry indices for a period of one month before and after elections.

Keywords : Investor Psychology, Election, Sensex, Stock Market, Volatility

\section{INTRODUCTION}

A stock market or equity market is the aggregation of buyers and sellers (a loose network of economic transactions, not a physical facility or discrete entity) of stocks (shares); these are securities listed on a stock exchange as well as those only traded privately. Stock market is one of the major economic reflectors. Indian economy is currently emerging as a global super power. Due to low labour cost and skillful manpower, sectors like textile, garments, manufacturing, banking and insurance have made a significant contribution to foster the growth potentials of the economy. There are several factors which are directly or indirectly related to stock prices. Here while observing stock market behavior we have taken into consideration Bombay Stock Exchange sensitive index (BSE SENSEX) in our database. Due to the asymmetric information community, most of the people who are involved in share
Market are not aware of the information for Trading. This paper tries to examine the impact of LokSabha polls-2014 on Bombay Stock Exchange (BSE) and its index Sensex.

\section{Indian General Elections}

The Lok Sabha or House of the People is the lower house of the Parliament of India. The Lok Sabha is composed of representatives of the people from 543 constituencies, chosen by direct election on the basis of adult suffrage. The Lok Sabha, unless sooner dissolved, continues to operate for five years from the date appointed for its first meeting and the expiration of the period of five years.

\section{Indian General Election of $\mathbf{2 0 1 4}$}

The Indian general election of 2014 was held to constitute the 16th Lok Sabha, electing members of parliament for all 543parliamentary constituencies of India. Running in nine phases

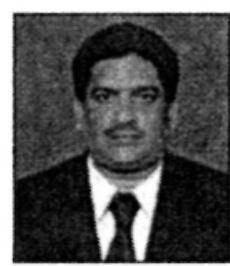

*Dr. Nagaraju Y

Associate Professor

Canara Bank School of Management Studies

Bangalore University 
from 7 April to 12 May 2014, this was the longest election in the country's history. According to the Election Commission of India, 814.5 million people were eligible to vote, with an increase of 100 million voters since the last general election in 2009, making this the largest-ever election in the world.

The results were declared on 16 May, fifteen days before the 15th LokSabha completes its constitutional mandate. The counting exercise was held at 989 counting centers. The National Democratic Alliance, led by the Bharatiya Janata Party, won a sweeping victory, taking 336 seats. The BJP itself won $31.0 \%$ of all votes and 282 $(51.9 \%)$ of all seats. It is the first time since the 1984 Indian general elections that a party has won enough seats to govern without the support of other parties. The United, led by the Indian National Congress, won 58 seats, $44(8.1 \%)$ of which were won by the Congress, that won $19.3 \%$ of all votes. It was the Congress party's worst defeat in a general election. BJP and its allies won a right to form the largest majority government since 1984 general election.

\section{LITERATURE REVIEW}

L.C. Gupta (1992) revealed the findings of his study that there is existence of wild speculation in the Indian stock market. The over speculative character of the Indian stock market is reflected in extremely high concentration of the market activity in a handful of shares to the neglect of the remaining shares and absolutely high trading velocities of the speculative counters. He opined that, short-term speculation, if excessive, could lead to "artificial price". An artificial price is one which is not justified by prospective earnings, dividends, financial strength and assets or which is brought about by speculators through rumours, manipulations, etc. He concluded that such artificial prices are bound to crash sometime or other as history has repeated and proved.

Debjit Chakraborty (1997) in his study attempts to establish a relationship between major economic indicators and stock market behaviour. $\mathrm{He}$ also analyses the stock market reactions to changes in the economic climate. The factors considered are inflation, money supply, and growth in GDP, fiscal deficit and credit deposit ratio. To find the trend in the stock markets, the BSE National Index of Equity Prices (Natex) which comprises 100 companies was taken as the index. The study shows that stock market movements are largely influenced by broad money supply, inflation, C/D ratio and fiscal deficit apart from political stability.

Bhanu Pant and Dr.T.R.Bishnoy (2001) analyzed the behaviour of the daily and weekly returns of five Indian stock market indices for random walk during April 1996 to June 2001. They found that Indian Stock Market Indices did not follow random walk.

\section{NEED FOR THE STUDY}

In the economic environment of the information age, the performance of the stock market is considered as an important indicator of the health of a nation's economy. Typically, the performance of any stock market is reflected through stock market prices. When the stock Market tumbles, investors and others become nervous about the Weakness of the economy. When the stock market is strong and steady, everyone senses economic prosperity. It can be difficult to predict the price of stocks, because those prices vary constantly based on a variety of factors.

Changes in local or global economic and political environment influence the share price movements and show the state of stock market to the general public. The issues of return and volatility have become increasingly important in recent times to the Indian investors, regulators, brokers, policy makers and researchers. Hence in this paper an attempt is made to understand the impact of LokSabha polls-2014 on BSE SENSEX during that period. 


\section{OBJECTIVES OF THE STUDY}

$>$ To study the comparison of stock prices before and after polls.

$>$ To examine the parameters which influence the Sensex during the LokSabha polls.

$>$ To study the behaviour of various sector during the polls in the BSE.

\section{DATAAND METHODOLOGY}

Data were collected from BSE Sensex. Sensex is a basket of 30 constituent stocks representing a sample of large, liquid and representative companies. Due to its wide acceptance amongst the Indian investors, Sensex is regarded as the pulse of Indian stock market. The data for this study was collected from BSE website for the period of one before and after elections. The data collected was divided into 4 weeks before and after polls based on each sector representing BSE Sensex. The data was analysed by using simple percentage to know the change in Index of each sector per week. This study is limited to only secondary data and the time period for this study is one month before and after the general elections 2014 .

\section{DATAANALYSIS AND INTERPRETATION}

The Sensex calculation has been done by taking share prices of all the thirty companies listed in Bombay Stock Exchange for the period of one month before and after election. Then the companies were divided on various sectors and calculated the average of share prices weekly wise. Then the average price percentage was calculated in order to know the exact number of change percentage per week. The tables and graphs below show the average Sensex price of different sectors of BSE Sensex. The study is limited to only secondary data and the time period for this data is one month before and after the general election 2014

Table 1: Average Sensex price for pre-poll \& post-poll election

\begin{tabular}{|c|c|c|c|c|}
\hline WEEK NO. & PRE POLL & \% CHANGE & POST POLL & \% CHANGE \\
\cline { 1 - 2 } 1 & 21808.61 & \multirow{2}{*}{$-0.12 \%$} & 24371.24 & \multirow{2}{*}{$0.34 \%$} \\
\cline { 1 - 2 } & 21782.93 & & 24454.79 & \\
\hline 3 & 22152.07 & $1.69 \%$ & 24953.05 & $2.04 \%$ \\
\hline 4 & 22450.55 & $1.35 \%$ & 25488.43 & $2.15 \%$ \\
\hline
\end{tabular}

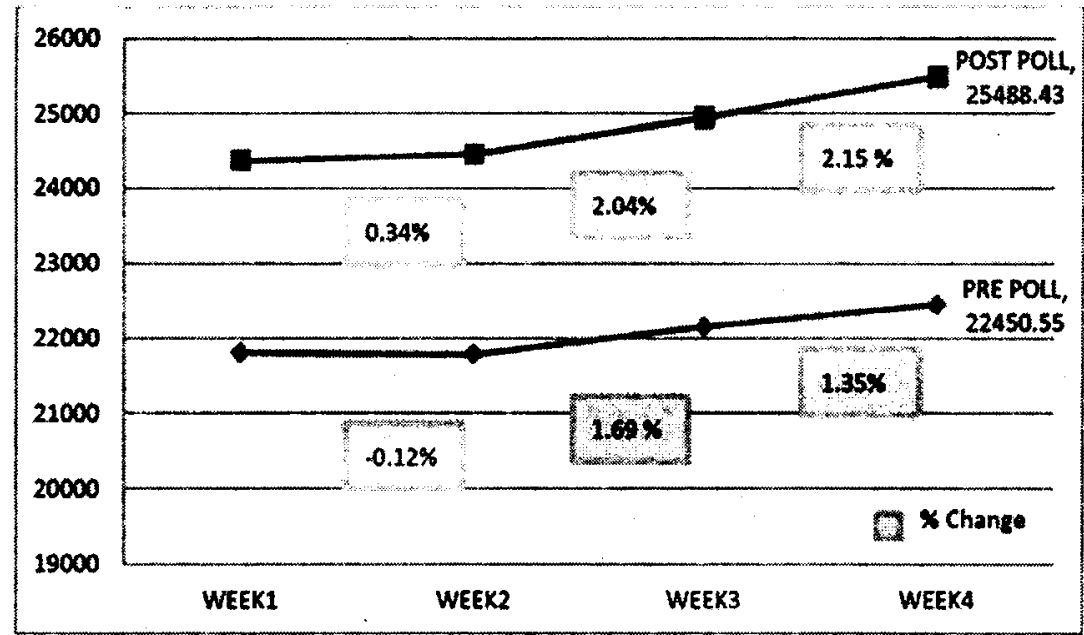

$2.15 \%$ of increase in share price during fourth week of post poll and decrease of $0.12 \%$ during second week of pre poll. 
What can be interpreted

Table 2: Average share price of automotive sector for pre-poll, post-poll election.

\begin{tabular}{|c|c|c|c|c|}
\hline WEEK NO. & PRE POLL & \% CHANGE & POST POLL & \% CHANGE \\
\cline { 1 - 2 } & 1437.14 & \multirow{2}{*}{$1.86 \%$} & 1620.92 & \multirow{2}{*}{$1.41 \%$} \\
\cline { 1 - 1 } 2 & 1463.9 & & 1643.86 & \\
\hline 3 & 1504.15 & $2.75 \%$ & 1708.42 & $3.93 \%$ \\
\hline 4 & 1530.72 & $1.77 \%$ & 1792.76 & $4.94 \%$ \\
\hline
\end{tabular}

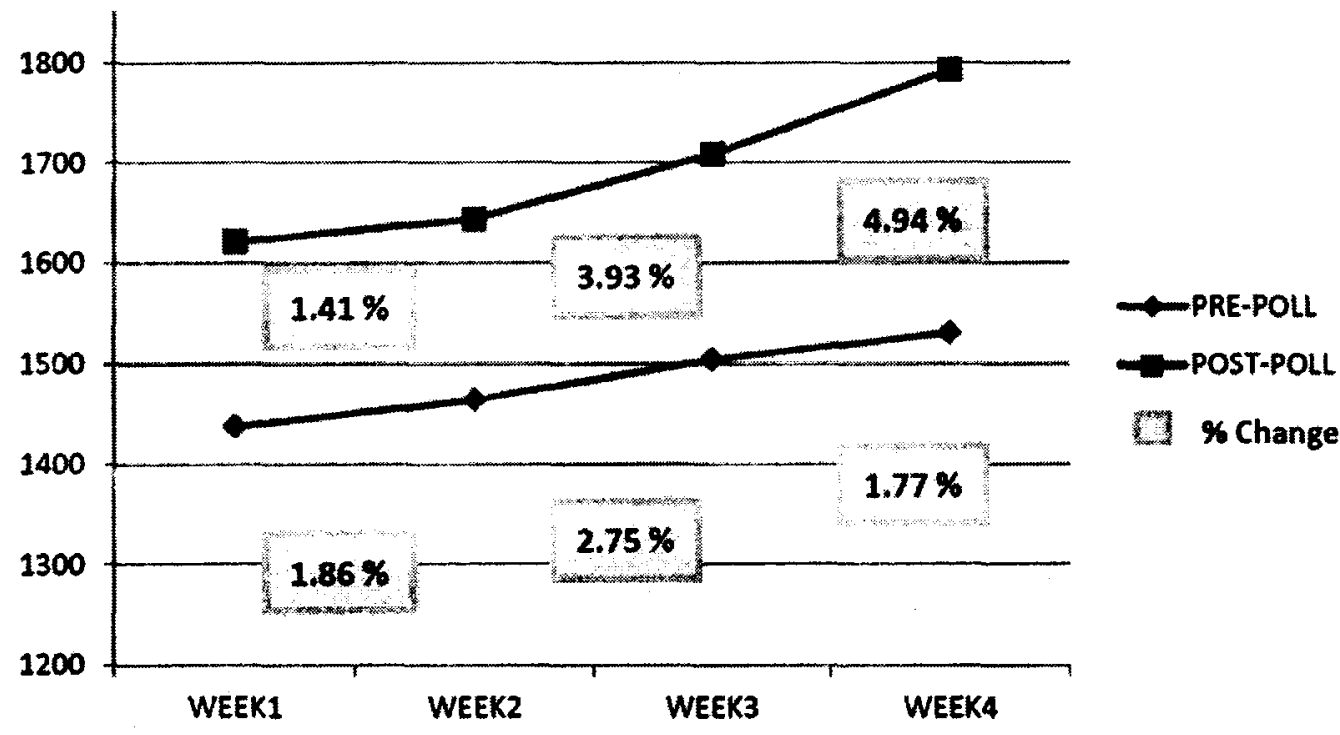

$4.94 \%$ increase in the share price during fourth week of post poll election, when compared to pre poll election during fourth week there is only $1.77 \%$ increase in the share price.

Table 3: Weekly average share price of banking sector for pre-poll, post-poll election

\begin{tabular}{|c|c|c|c|c|}
\hline WEEK NO. & PRE POLL & \% CHANGE & POST POLL & \% CHANGE \\
\hline 1 & 1248.3 & \multirow{2}{*}{$0.31 \%$} & 1658.22 & \multirow{2}{*}{$1.35 \%$} \\
\cline { 1 - 1 } & 1252.23 & & 1680.65 & \\
\hline 3 & 1305.89 & $4.29 \%$ & 1722.98 & $2.52 \%$ \\
\hline 4 & 1332.79 & $2.06 \%$ & 1719.22 & $-0.22 \%$ \\
\hline
\end{tabular}




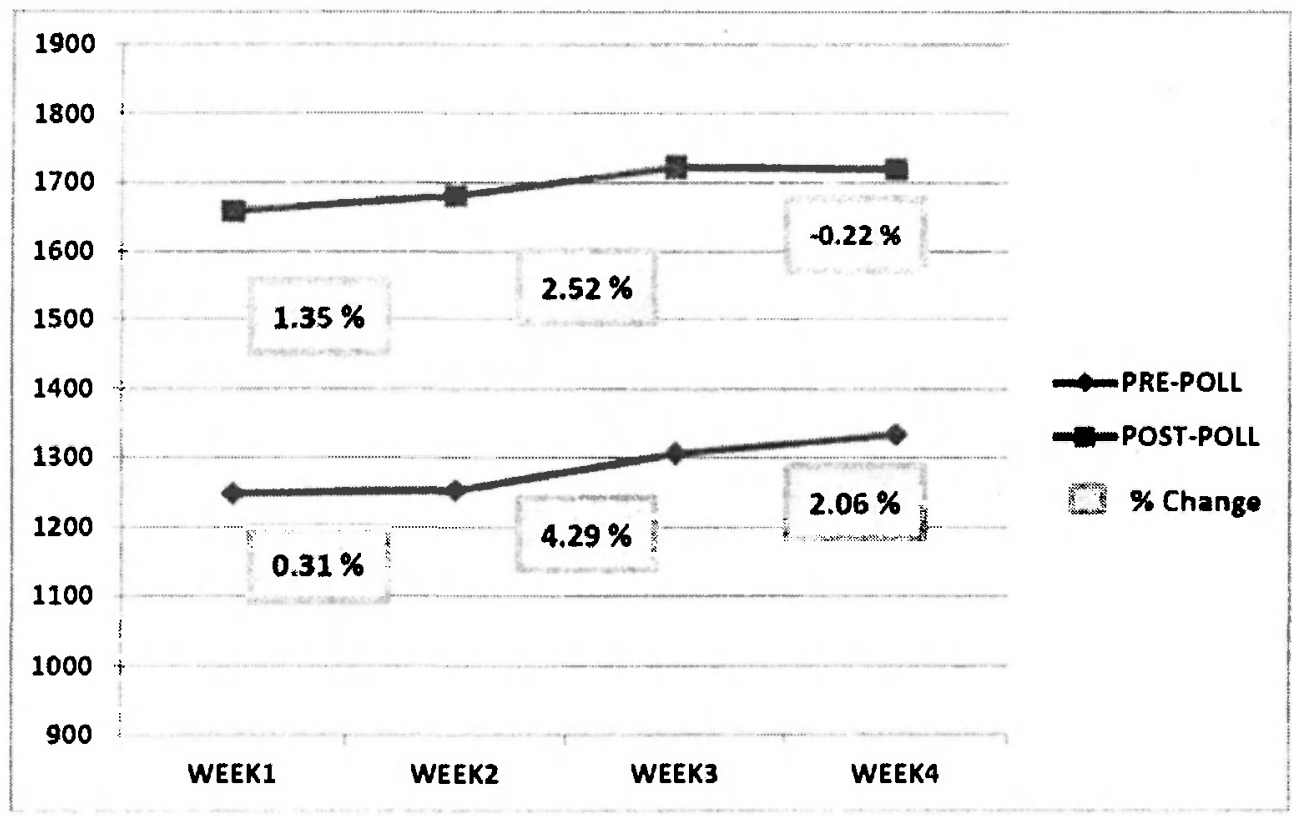

During post poll there was an increase of $2.52 \%$ in third week and decrease of $0.22 \%$ in fourth week and in pre poll there was an increase of $4.29 \%$ in third week and minor increase in the second week of $0.31 \%$.

Table 4: weekly average share price of IT/Software sector for pre-poll, post-poll election

\begin{tabular}{|c|c|c|c|c|}
\hline WEEK NO. & PRE POLL & \% CHANGE & POST POLL & \% CHANGE \\
\hline 1 & 2103.11 & \multirow{2}{*}{$-5.48 \%$} & 1897.72 & \multirow{2}{*}{$0.24 \%$} \\
\cline { 1 - 2 } & 1987.88 & & 1902.22 & \\
\hline 3 & 1974.22 & $-0.68 \%$ & 1871.55 & $-1.61 \%$ \\
\hline 4 & 2008.29 & $1.73 \%$ & 1941.77 & $3.75 \%$ \\
\hline
\end{tabular}

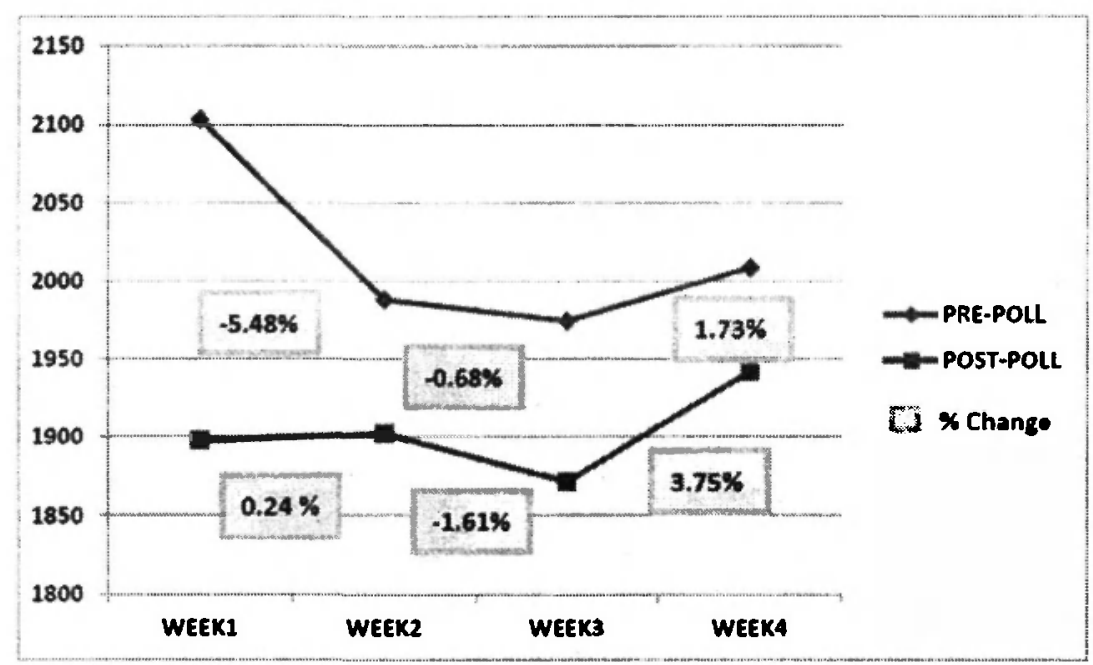

There was a major decrease of $5.48 \%$ during second week of pre poll election and in the post poll election we could see a sharp increase of $3.75 \%$ of share price in the fourth week. 
Table 5: weekly average share price of Pharmaceutical sector for pre-poll, post-poll election

\begin{tabular}{|c|c|c|c|c|}
\hline WEEK NO. & PRE POLL & \% CHANGE & POST POLL & \% CHANGE \\
\hline 1 & 1228.84 & \multirow{2}{*}{$1.96 \%$} & 1098.87 & \multirow{2}{*}{$1.23 \%$} \\
\cline { 1 - 2 } 2 & 1252.92 & & 1112.4 & \\
\hline 3 & 1206.89 & $-3.67 \%$ & 1111.79 & $0.05 \%$ \\
\hline 4 & 1195 & $-0.99 \%$ & 1148.49 & $3.03 \%$ \\
\hline
\end{tabular}

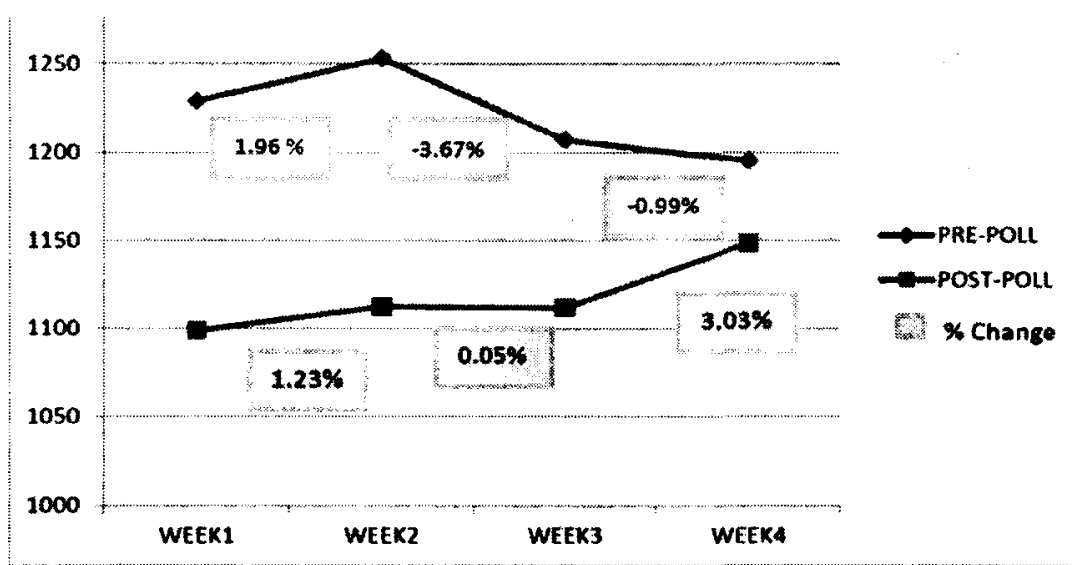

During the pre poll election there was a sharp decline of $3.67 \%$ in the third week, and during the post poll election we could see increase in the share price of pharmaceutical sector in the fourth week.

Table 6: weekly average share price of Metal, Mining sector for pre-poll, post-poll election

\begin{tabular}{|c|c|c|c|c|}
\hline WEEK NO. & PRE POLL & \% CHANGE & POST POLL & \% CHANGE \\
\cline { 1 - 2 } 1 & 185.66 & \multirow{2}{*}{$0.24 \%$} & 257.87 & \multirow{2}{*}{$4.61 \%$} \\
\cline { 1 - 2 } 2 & 186.1 & & 269.75 & \\
\hline 3 & 194.15 & $4.32 \%$ & 282.45 & $4.71 \%$ \\
\hline 4 & 204.49 & $5.33 \%$ & 289.18 & $2.38 \%$ \\
\hline
\end{tabular}

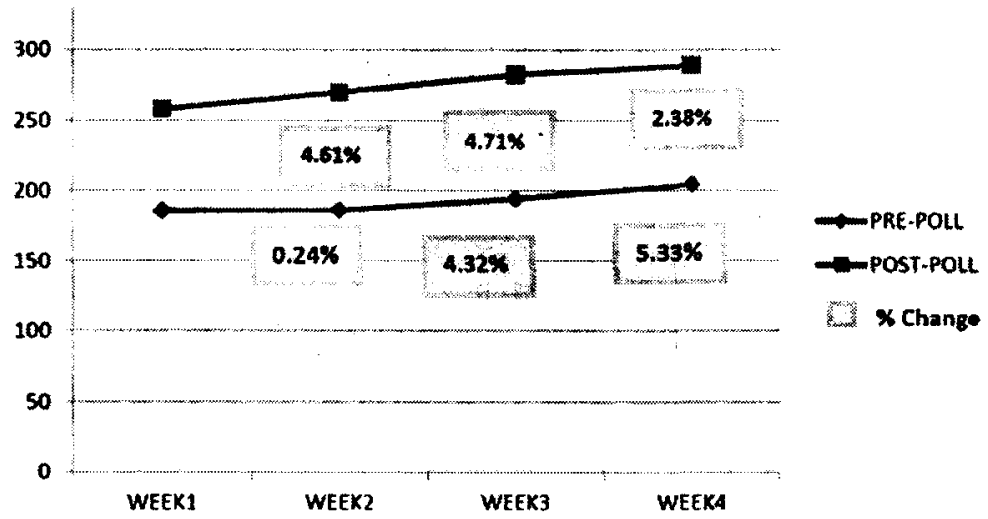

There was an increase of $5.33 \%$ during the fourth week of pre poll election and in contrast there was an increase of $4.71 \%$ during the third week of post poll election. 
Table 7: weekly average share price of Petroche mical sector for pre-poll, post-poll election

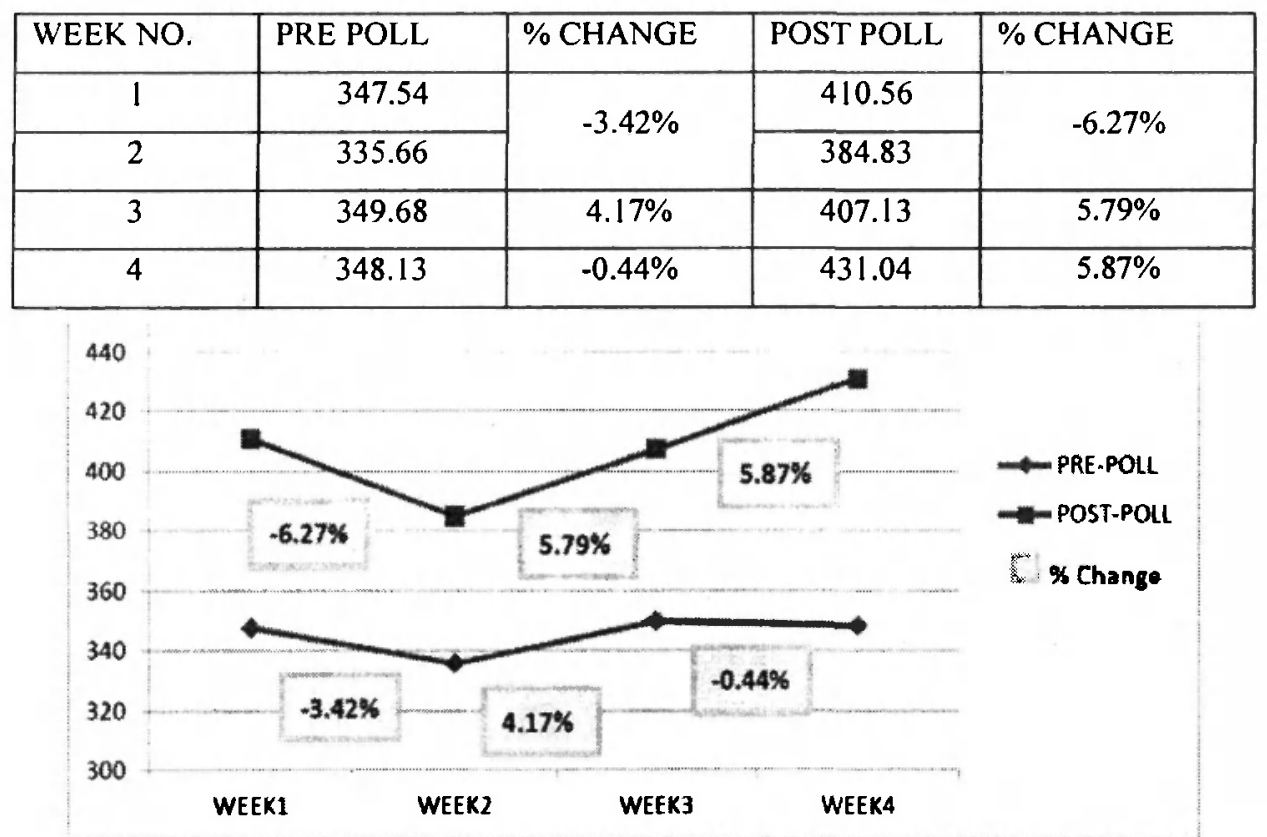

There was an increase in the share price of $5.87 \%$ in the fourth week and decrease of $6.27 \%$ in the second week of post poll election, there was also increase of $4.17 \%$ during the third week and decrease in the second week of $3.42 \%$ during pre-poll election.

Table 8: weekly average share price of Electric sector for pre-poll, post-poll election

\begin{tabular}{|c|c|c|c|c|}
\hline WEEK NO. & PRE POLL & \% CHANGE & POST POLL & \% CHANGE \\
\hline 1 & 128.07 & \multirow{2}{*}{$-0.27 \%$} & 169.46 & \multirow{2}{*}{$0.81 \%$} \\
\cline { 5 - 5 } & 127.72 & & 168.09 & \\
\hline 3 & 131.4 & $2.88 \%$ & 176.19 & $4.82 \%$ \\
\hline 4 & 132.58 & $0.90 \%$ & 172.83 & $-1.91 \%$ \\
\hline
\end{tabular}

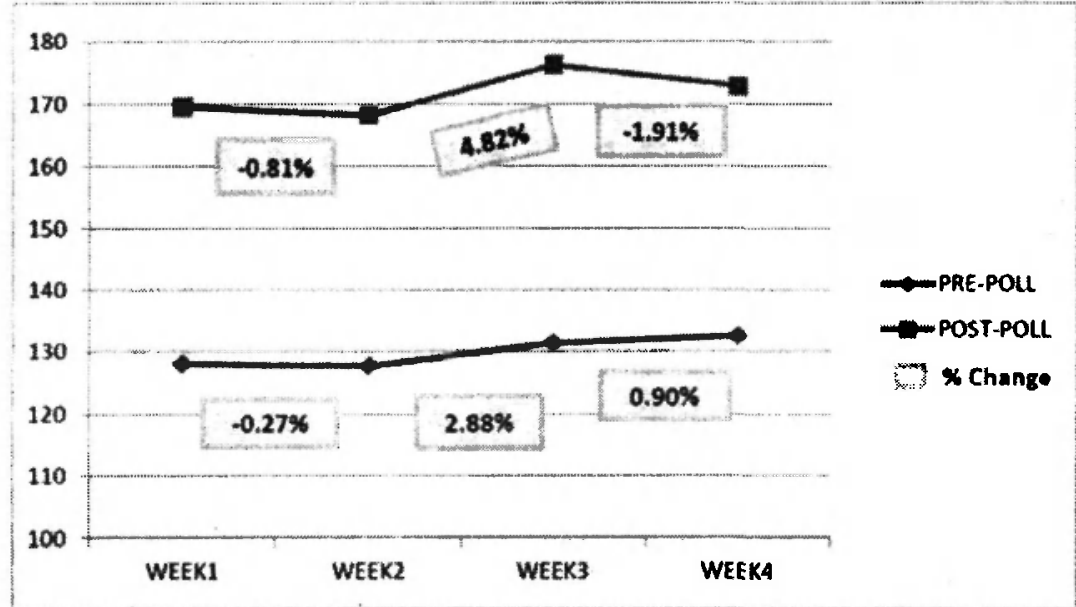

There was an increase in the electric sector during third week of post poll election of $4.82 \%$ and there was decrease of $1.91 \%$ during fourth week of post poll election and in the other hand increase of $2.88 \%$ in the third week and decrease of $0.27 \%$ in the second week of pre poll election. 
Table 9: weekly average share price of Conglomerate sector for pre-poll, post-poll election

\begin{tabular}{|c|c|c|c|c|}
\hline WEEK NO. & PRE POLL & \% CHANGE & POST POLL & \% CHANGE \\
\hline 1 & 608.68 & \multirow{2}{*}{$2.89 \%$} & 721.04 & \multirow{2}{*}{$-1.09 \%$} \\
\cline { 1 - 2 } & 626.3 & & 713.19 & \\
\hline 3 & 629.12 & $0.45 \%$ & 713.45 & $0.04 \%$ \\
\hline 4 & 647.38 & $2.90 \%$ & 720.05 & $0.92 \%$ \\
\hline
\end{tabular}

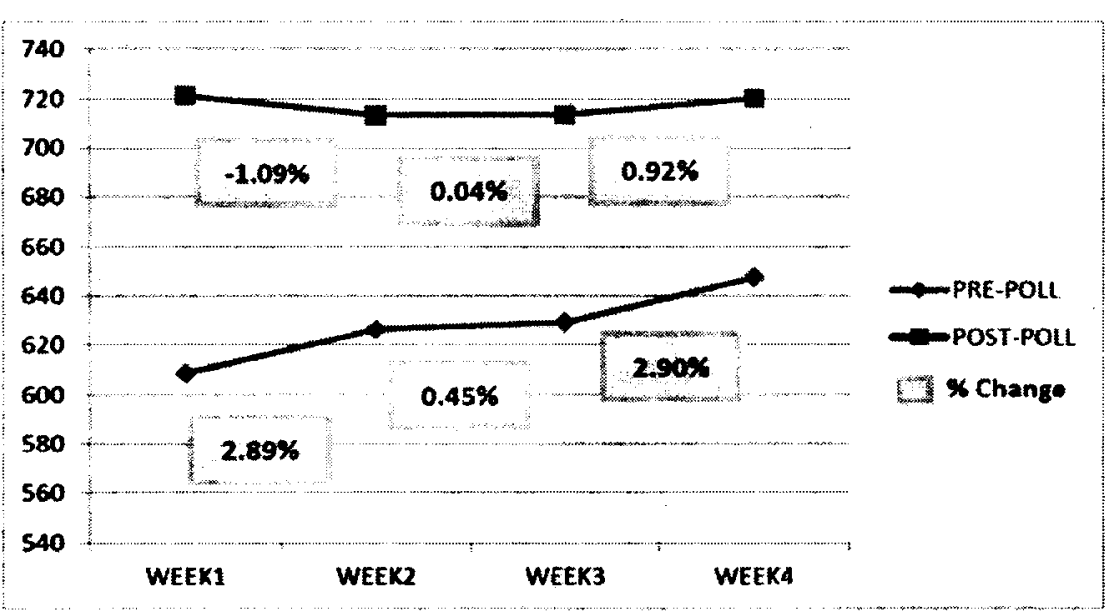

There was an increase of $2.90 \%$ during the fourth week of pre poll election and on the other side there was a decrease of $1.09 \%$ during the second week and increase of $0.92 \%$ in the fourth week of post poll election.

Table 10: weekly average share price of Consumer goods sector for pre-poll, post-poll election

\begin{tabular}{|c|c|c|c|c|}
\hline WEEK NO. & PRE POLL & \% CHANGE & POST POLL & \% CHANGE \\
\hline 1 & 557.17 & \multirow{2}{*}{$1.81 \%$} & 564.58 & \multirow{2}{*}{$0.64 \%$} \\
\cline { 1 - 2 } 2 & 567.26 & & 568.18 & \\
\hline 3 & 592.15 & $4.39 \%$ & 613.6 & $7.99 \%$ \\
\hline 4 & 602.41 & $1.73 \%$ & 631.96 & $2.99 \%$ \\
\hline
\end{tabular}

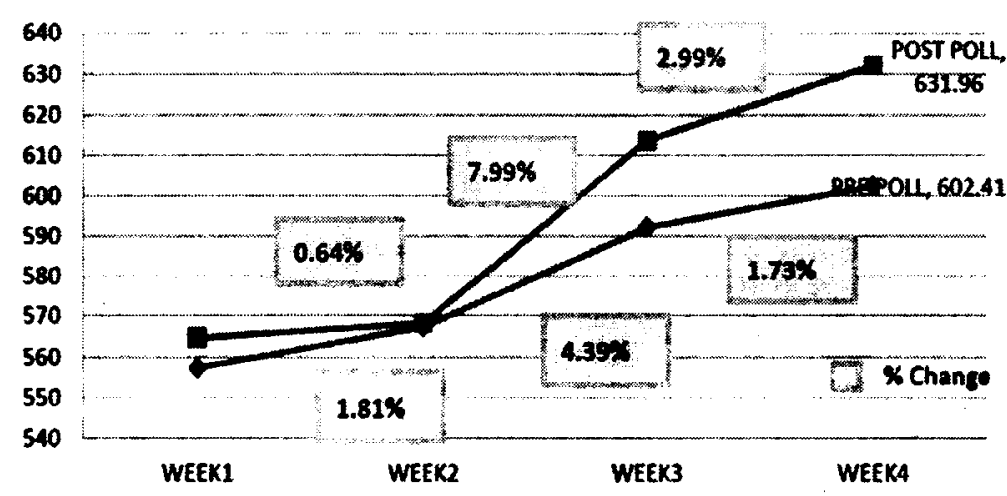

There was a tremendous increase from both the period, we could see an increase of $7.99 \%$ during the third week of post poll election and also increase in the pre poll election of $4.39 \%$ during the third week of pre poll election of the consumer goods sector. 
Table 11: weekly average share price of Telecommunication sector for pre-poll, post-poll election

\begin{tabular}{|c|c|c|c|c|}
\hline WEEK NO & PRE POLL & $\%$ CHANGE & POST POLL & $\%$ CHANGE \\
\hline 1 & 300.83 & \multirow{2}{*}{$-1.87 \%$} & 338.97 & \multirow{2}{*}{$0.17 \%$} \\
\hline 2 & 295.19 & & 339.55 & \\
\hline 3 & 303.23 & $2.72 \%$ & 357.13 & $5.18 \%$ \\
\hline 4 & 319.73 & $5.44 \%$ & 349.27 & $-2.20 \%$ \\
\hline
\end{tabular}

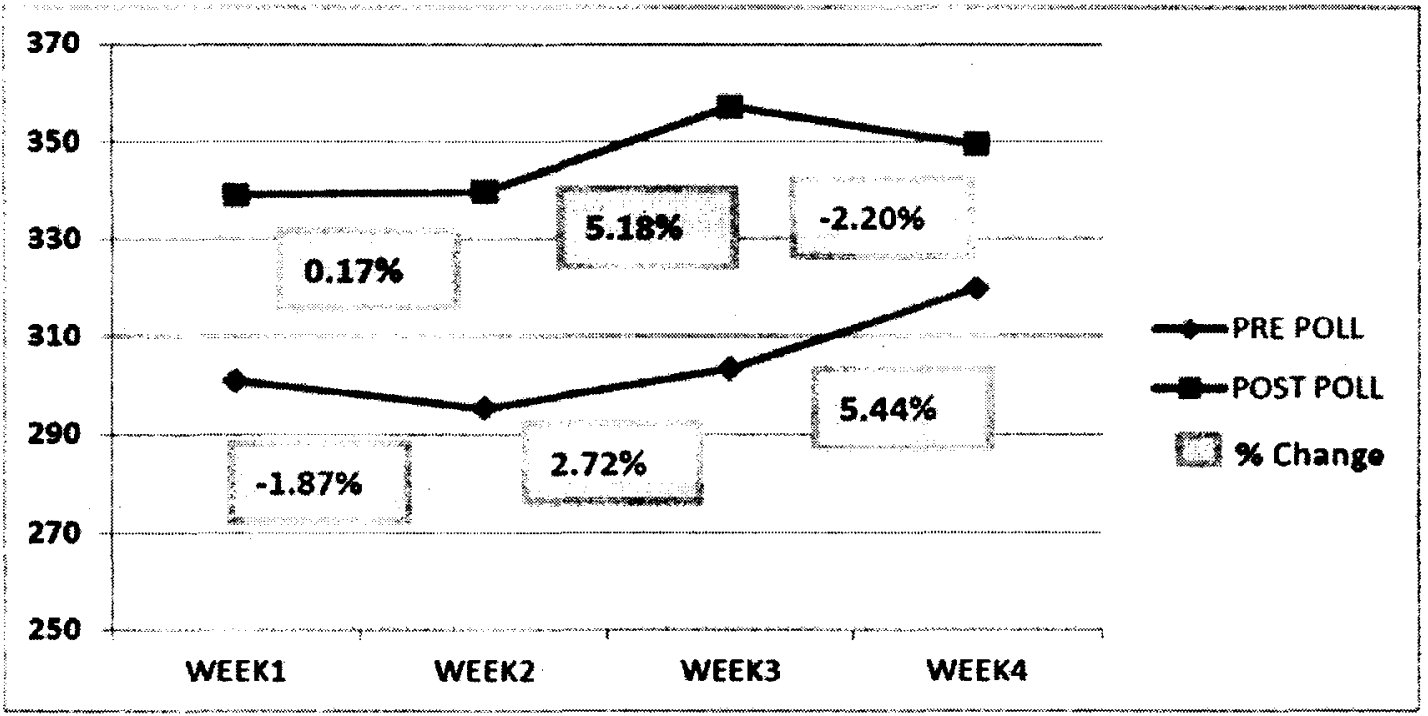

There was an increase in the telecommunication sector during the pre poll election of $5.44 \%$ in the fourth week and decrease of $1.87 \%$ in the second week, and on the other side there was an increase of $5.18 \%$ during the third week and decrease of $2.20 \%$ in the fourth week of post poll election.

Table 12: weekly average share price of Infrastructure sector for pre-poll, post-poll election

\begin{tabular}{|c|c|c|c|c|}
\hline WEEK NO. & PRE POLL & \% CHANGE & POST POLL & \% CHANGE \\
\hline 1 & 1227.35 & \multirow{2}{*}{$0.11 \%$} & 1488.08 & \multirow{2}{*}{$4.64 \%$} \\
\cline { 1 - 2 } & 1228.76 & & 1557.2 & \\
\hline 3 & 1265.11 & $2.96 \%$ & 1668.01 & $7.11 \%$ \\
\hline 4 & 1283.21 & $1.43 \%$ & 1721.84 & $3.22 \%$ \\
\hline
\end{tabular}




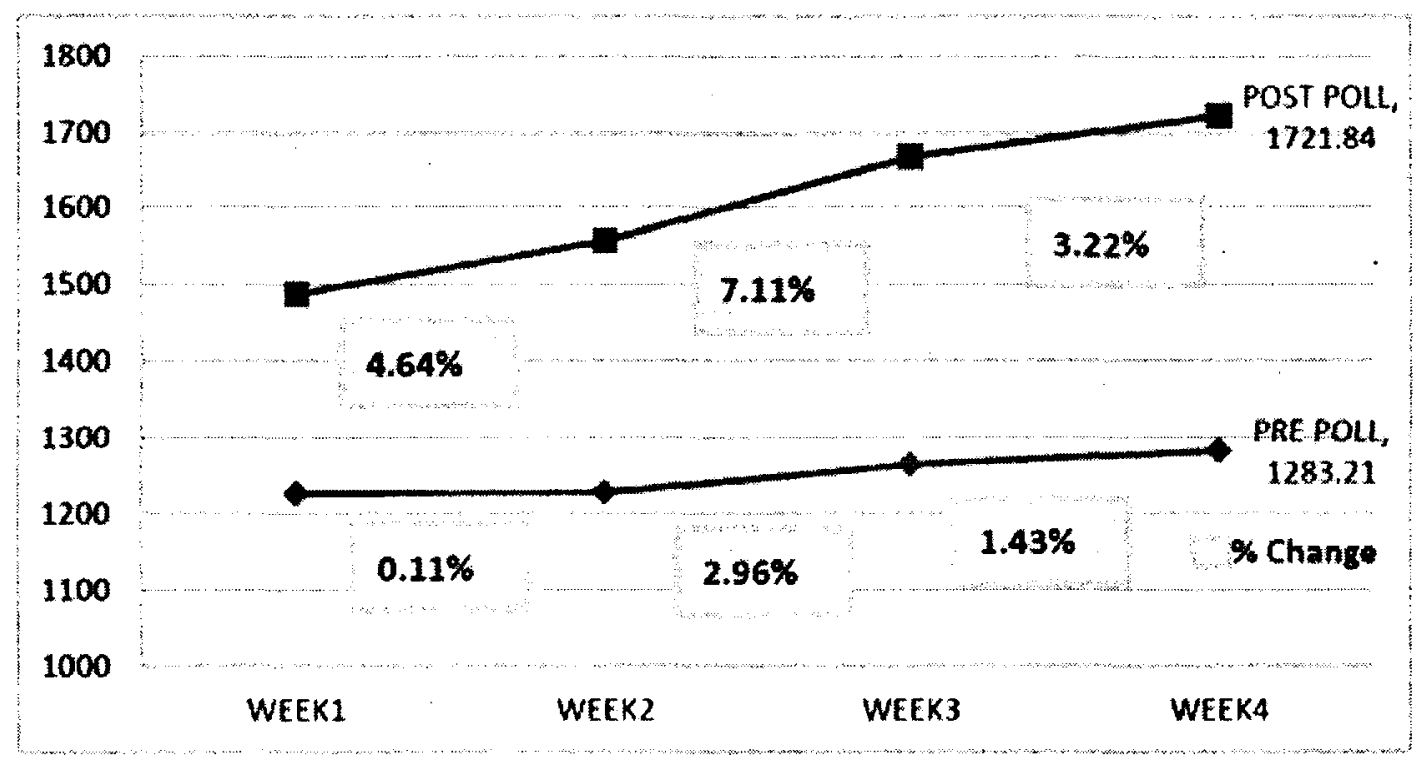

There was an increase in the Infrastructure sector overall. There was an increase in the post poll election of $7.11 \%$ during the third week and on the other side there was an increase of $2.96 \%$ in the third week of pre poll election.

\section{FINDINGS}

- Overall Sensex during fourth week of post poll was increased by $2.15 \%$ and decrease of $0.12 \%$ during second week of pre poll.

- In automotive sector during fourth week of post poll election there was an increase of $4.94 \%$, when compared to pre poll election during fourth week there was only $1.77 \%$ increase in the share prices.

- In the Banking sector there was an increase of $2.52 \%$ in third week and decrease of $0.22 \%$ in fourth week and in pre poll there is increase of $4.29 \%$ in third week and minor increase in the second week of $0.31 \%$.

- There was a major decrease in the share price of IT Software sector of $5.48 \%$ during second week of pre poll election and in the post poll election we could see a sharp increase of $3.75 \%$ of share price in the fourth week.
- During the pre poll election there is a sharp decline of $3.67 \%$ in the third week, and during the post poll election we could see increase in the share price of pharmaceutical sector in the fourth week.

- In the Mining sector there was a sharp increase of $5.33 \%$ during the fourth week of pre poll election and in contrast there was increase of $4.71 \%$ during the third week of post poll election.

- In Petrochemical sector there was an increase of $5.87 \%$ in the fourth week and decrease of $6.27 \%$ in the second week of post poll election, there was also increase of $4.17 \%$ during the third week and decrease in the second week of $3.42 \%$ during pre poll election.

- There was sharp increase in the electric sector during third week of post poll election of $4.82 \%$ and there was decrease of $1.91 \%$ during fourth week of post poll 
election and in the other hand increase of $2.88 \%$ in the third week and decrease of $0.27 \%$ in the second week of pre poll election.

- In Conglomerate sector there was increase of $2.90 \%$ during the fourth week of pre poll election and on the other side there was sharp decrease of $1.09 \%$ during the second week and increase of $0.92 \%$ in the fourth week of post poll election.

- In Consumer Goods sector there was an increase of $7.99 \%$ during the third week of post poll election and also there was an increase in the pre poll election by $4.39 \%$ during the third week.

- In the Telecommunication sector there was an increase of $5.44 \%$ in the 4 th week of pre poll election and on the other side there is increase of $5.18 \%$ during the third week and decrease of $2.20 \%$ in the fourth week of post poll election.

- In infrastructure sector there was an increase of $7.11 \%$ during the third week of post poll and on the other side there wasan increase of $2.96 \%$ in the third week of pre poll election.

\section{CONCLUSION}

Stock prices are changed every day by the market. Buyers and Sellers cause prices to change as they decide how valuable each stock is. Basically share prices change because of supply and demand. Apart from supply and demand, there are several factors which directly or indirectly influence stock prices. One of such factors is general elections 2014. From this study we can conclude that there is significant increase in Sensex for a period of one month before and after elections. The investors and stock market reacted positively to general elections 2014, hoping new government will formulate policies to revive industry and economy.

\section{References}

- L.C.Gupta (1992), "Stock Trading in India", Society for Capital Market Research and Development, Delhi

- Amanulla S and Kamaiah B (1995): Market Integration as an Alternative test of Market Efficiency: A case of Indian stock Market. ArthaVijana, September N 3 PP 215-230

- Arun Jeth Malani, "Risky Business", The Economics Times, Daily, July 1st 1999, p12

- Juhi Ahuja (2012), "Indian Capital Market: An Overview with Its Growth" VSRD International Journal of Business \& Management Research Vol. 2 (7), pp. 386399

- Frankie Chaua, Rataporn Deesomsaka and Jun Wang, Political uncertainty and stock market volatility in the Middle East and North African (MENA) countries, Journal of International Financial Markets Institutions and Money, Vol 28, Jan 2014, pp 1-19

- John W. Goodella and Sami Vahamaab, US presidential elections and implied volatility: The role of political uncertainty, Journal of Banking \& Finance, Vol 37 Iss 3, March 2013, pp 1108-1117

- Maitreesh Ghatak, Parikshit Ghosh, and Ashok Kotwal, Growth in the time of UPA: Myths and Reality, Vancouver School of Economics

- Chung-Chu Chuanga and Yi-HsienWangb, 
Electoral information in developed stock market: testing conditional heteroscedasticity in the market model, Applied Economics, Volume 42 Issue 9, pp 1125-1131

- Ankita Mishra, Vinod Mishra, and Russell Smyth, The Random-Walk Hypothesis on the Indian Stock Market, Department of Economics, Monash University

- Brandice Canes-Wrone and Jee-Kwang
Park, Elections, Uncertainty and Irreversible Investment, British Journal of Political Science, Volume 44 Issue 1, Jan 2014, pp 83-106

- Andrew Wyatt, India in 2013: Braced for an Election, University of California Press, Vol. 54, Iss. 1, (January/February 2014), pp. 151-164 